San Antonio Review • San Antonio Review (Volume IV | Fall 2020)

\title{
The Lottery
}

\section{Emily Bilman}

Published on: Oct 14, 2020

DOI: $10.21428 / 9 b 43 c d 98.205 e b d 1 c$

License: Creative Commons Attribution 4.0 International License (CC-BY 4.0). 


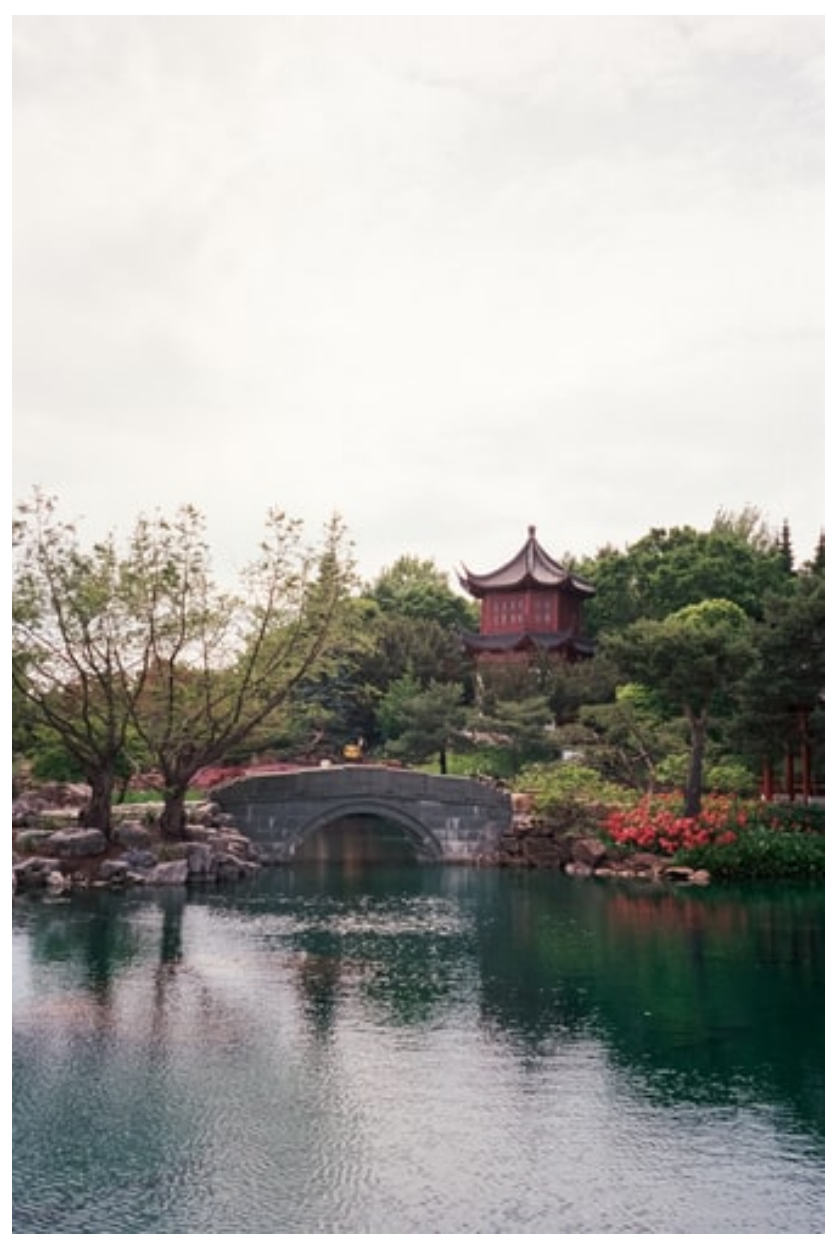

Photo by Hansel Wong on Unsplash

Under the auspicious gaze of the Minerva statue in their living room, Phyllis and Florian were preparing their trip to the Montréal botanical gardens. They were retired botanists.

Florian remembered his botanical mission to Taiwan and said:

"We could re-design our garden with the waterscapes of the Japanese gardens."

Phyllis continued: "The exotic exhibit of orchids, irises, and amaryllis should be a treat of colours."

He added: "The arboretum with its pine, and maple varieties and the medicinal plant garden with its rows of lavender, sage, and milk thistle will be splendid."

Enthused, Phyllis, then, decided to go to town. She kissed Florian goodbye and took the car. She parked in Exchange Street. Along the avenue leading to the stock exchange, she crossed the bronze statue of blindfolded Themis holding her scales of justice. 
In the shopping mall, she bought a lottery ticket, knowing it was inflated to thrice its price. It would be drawn tonight. Walking away from Thetis towards her car, two masked rascals grabbed her bag and ran away quickly. Phyllis collapsed on the concrete pavement. Shocked, she asked a passer-bye to call her husband.

She straightened up, realizing she had spent too much of saved money on a lost lottery ticket. Florian had arrived with a surprise. He had reserved dinner-for-two in a Taiwanese restaurant with mottled carp ponds lit with red lanterns. He took her hand. Phyllis began to cry like an inconsolable little girl who had broken her favourite porcelain tea set.

Dr. Emily Bilman is London Poetry Society's Stanza representative in Geneva where she lives and teaches poetry. Her dissertation, The Psychodynamics of Poetry, was published by Lambert Academic in 2010 and Modern Ekphrasis in 2013 by Peter Lang, CH. Three poetry books, A Woman By_A Well, Resilience, and The Threshold of Broken Waters were published by Troubador, UK.. Her poems, essays, and translations of Neruda and Valéry appeared in The Battersea Review, Hunger Mountain, The High Window, The Journal of Poetics Research, Tuck Magazine, Offshoots, Expanded Field, and The London Magazine. "The Tear-Catcher" won the first prize for depth poetry in The New York Literary Magazine. She edits and writes poems and essays for a digital ekphrastic publication. Her latest poetry book, Apperception, was published by Troubador in September 2020. Her short fiction piece “The Gun" appeared in Talking Soup. 